(C) 2021, The Authors. Published by Elsevier Inc. and Fass Inc. on behalf of the American Dairy Science Association ${ }^{\circledR}$. This is an open access article under the CC BY-NC-ND license (http://creativecommons.org/licenses/by-nc-nd/4.0/).

\title{
Estimating methane coefficients to predict the environmental impact of traits in the Australian dairy breeding program
}

\author{
C. M. Richardson, ${ }^{1,2} \odot$ P. R. Amer, ${ }^{3} \odot$ F. S. Hely, ${ }^{3} \odot$ I. van den Berg, ${ }^{1}{ }^{\oplus}$ and J. E. Pryce ${ }^{1,2 *} \odot$ \\ ${ }_{1}^{1}$ Agriculture Victoria Research, AgriBio, Centre for AgriBioscience, Bundoora, Victoria 3083, Australia \\ ${ }^{2}$ School of Applied Systems Biology, La Trobe University, Bundoora, Victoria 3083, Australia \\ ${ }^{3}$ AbacusBio Limited, PO Box 5585, Dunedin, New Zealand
}

\begin{abstract}
The dairy industry has been scrutinized for the environmental impact associated with rearing and maintaining cattle for dairy production. There are 3 possible opportunities to reduce emissions through genetic selection: (1) a direct methane trait, (2) a reduction in replacements, and (3) an increase in productivity. Our aim was to estimate the independent effects of traits in the Australian National Breeding Objective on the gross methane production and methane intensity $(E I)$ of the Australian dairy herd of average genetic potential. Based on similar published research, the traits determined to have an effect on emissions include production, fertility, survival, health, and feed efficiency. The independent effect of each trait on the gross emissions produced per animal due to genetic improvement and change in $E I$ due to genetic improvement (intensity value, $I V$ ) were estimated and compared. Based on an average Australian dairy herd, the gross emissions emitted per cow per year were $4,297.86 \mathrm{~kg}$ of carbon dioxide equivalents $\left(\mathrm{CO}_{2}\right.$-eq). The annual product output, expressed in protein equivalents (protein-eq), and $E I$ per cow were $339.39 \mathrm{~kg}$ of protein-eq and $12.67 \mathrm{~kg}$ of $\mathrm{CO}_{2^{-}}$ $\mathrm{eq} / \mathrm{kg}$ of protein-eq, respectively. Of the traits included in the National Breeding Objective, genetic progress in survival and feed saved were consistently shown to result in a favorable environmental impact. Conversely, production traits had an unfavorable environmental impact when considering gross emissions, and favorable when considering EI. Fertility had minimal impact as its effects were primarily accounted for through survival. Mastitis resistance only affected $I V$ coefficients and to a very limited extent. These coefficients may be used in selection indexes to apply emphasis on traits based on their environmental impact, as well as applied by governments and stakeholders to track trends in industry emissions. Although initiatives are underway
\end{abstract}

Received February 22, 2021.

Accepted June 8, 2021.

*Corresponding author: jennie.pryce@agriculture.vic.gov.au to develop breeding values to reduce methane by combining small methane data sets internationally, alternative options to reduce emissions by utilizing selection indexes should be further explored.

Key words: sustainability, environmental impact, methane, emission intensity, gross emissions

\section{INTRODUCTION}

In 2016, Australia committed to reduce greenhouse gas (GHG) emissions by 26 to $28 \%$ of 2005 levels by 2030 (UNFCCC, 2016). This target relies largely on a decrease in the 3 major GHG, carbon dioxide $\left(\mathrm{CO}_{2}\right)$, methane $\left(\mathrm{CH}_{4}\right)$, and nitrous oxide, which account for $81 \%, 10 \%$, and $7 \%$ of the global GHG inventory, respectively (EPA, 2020). For the Australian dairy sector, the primary GHG targeted to reduce its environmental impact is $\mathrm{CH}_{4}$ as it accounts for $57 \%$ of the industry's emissions (UNFCCC, 2018).

Methane is associated with DMI as $90 \%$ is generated as a by-product of feed fermentation, with $6 \%$ to $11 \%$ of the energy in feed being lost to the production of $\mathrm{CH}_{4}$ (Appuhamy et al., 2016). The genetic correlation between $\mathrm{CH}_{4}$ and DMI has been previously estimated between 0.3 and 0.6 (Difford et al., 2020; Richardson et al., 2021b; Manzanilla-Pech et al., 2021), suggesting that the genetic architecture of these traits is similar. However, the relationship between the general selection criteria for methane emissions and feed efficiency, of which $\mathrm{CH}_{4}$ and DMI are component traits, is contested in dairy cattle (Løvendahl et al., 2018; González-Recio et al., 2020). Some studies have shown that $\mathrm{CH}_{4}$ per unit of feed decreases with increasing levels of DMI (Jentsch et al., 2007) and that improving feed efficiency causes a decrease in $\mathrm{CH}_{4}$ (Basarab et al., 2013). However, Flay et al. (2019) reported no decrease in daily $\mathrm{CH}_{4}$ with increasing feed efficiency, but did show increases in $\mathrm{CH}_{4}$ per unit feed. This indicates that mitigation strategies focused on solely reducing $\mathrm{CH}_{4}$ emission through genetic improvement in feed efficiency traits may not be satisfactory in lowering dairy cattle emissions, and that additional methods are required. 
Large-scale research initiatives (such as the Efficient Dairy Genome Project, 2016) are focused on developing genetic strategies to mitigate dairy cattle $\mathrm{CH}_{4}$ emissions; however, EBV for $\mathrm{CH}_{4}$ are not yet widely available. Measuring $\mathrm{CH}_{4}$ is expensive and labor intensive, leading to small data sets. Additionally, recording protocols vary between studies, limiting the ability to combine data sets (nationally or internationally), as has been done successfully for traits with similar issues, such as DMI (de Haas et al., 2017; Hristov et al., 2018). Therefore, until reliable $\mathrm{CH}_{4} \mathrm{EBV}$ are ready for industry application, other mitigation options should be explored. Many traits, direct and proxy, have been suggested to decrease $\mathrm{CH}_{4}$. However, Wall et al. (2010) suggested that the environmental impact of livestock may also be decreased by improving individual animal productivity and efficiency, and by reducing overall waste at the herd level.

Selection indexes are traditionally comprised of traits with direct economic benefit to the producer, including production, fertility, and health. Therefore, a value must be assigned to $\mathrm{CH}_{4}$ to give it a comparative weight in a selection index. In the case of $\mathrm{CH}_{4}$, defining an economic value is challenging as only marginal value directly related to improve feed efficiency exist, and many have recorded the economic value as zero (FAO, 2013). In regions where a carbon tax has been placed on agriculture, the market value of carbon may be used. However, no such tax currently exists in Australia, so this approach cannot be applied to estimate a direct value for the Australian dairy industry.

Amer et al. (2018) developed a methodology of monitoring and estimating the independent effect that index traits have on the environment for any GHG or production system. This method has since been adapted to investigate the environmental impact of the dairy and beef industry, and to estimate possible environmental index weights in beef and dairy systems internationally (Quinton et al., 2018; Zhang et al., 2019; Richardson et al., 2021a).

The aim of this research was to calculate coefficients that describe the change in $\mathrm{CH}_{4}$ attributed to each index trait in the Australian dairy selection index described in gross methane and methane intensity, which may be applied as weights in a selection index to account for the environmental impact of traits.

\section{MATERIALS AND METHODS}

The method used in this study was based on the approach used by Amer et al. (2018) and adapted to calculate the independent effects of traits in the Australian National Breeding Objective (NBO), on the gross methane production and methane intensity of an
Australian dairy herd of average genetic merit. Briefly, this method estimates the change in total emissions and product output caused by a 1-unit change in each index trait, resulting from either a direct emissions trait (methane yield), changes in herd structure (fewer replacements), or the dilution effect of higher yields (milk production) and proliferation (more offspring/ dam). A primary assumption of this study is that the $\mathrm{CH}_{4}$ emitted is directly proportional to the total feed consumed, as approximately $90 \%$ of the $\mathrm{CH}_{4}$ emitted by cattle is produced as a by-product of feed fermentation and released as enteric $\mathrm{CH}_{4}$ (Ellis et al., 2008).

\section{Average Australian Herd}

Parameters in this study (Table 1) were assumed to be representative of the average Australian dairy herd, consisting of cows with an average 305-d production of $6,861.00 \mathrm{~kg}$ milk per cow at $4.00 \%$ fat, $3.30 \%$ protein and $4.80 \%$ lactose (DataGene Ltd., 2017). The average feed required per lactating cow was taken as a weighted average of the feed energy required per parity $(7,207.58$ $\mathrm{kg}$ of DM; Méndez et al., 2020). The estimated total feed required by a growing heifer $(3,526.75 \mathrm{~kg}$ of DM) was determined based on the feed required to reach 90\% of adult BW (Williams et al., 2011), the average of which was estimated to be $600 \mathrm{~kg}$ (Byrne et al., 2016). The energy contents of lactating cow and replacement heifer diets were assumed to be $11.91 \mathrm{MJ} \mathrm{ME} / \mathrm{kg}$ of $\mathrm{DM}$ and $9.27 \mathrm{MJ} \mathrm{ME} / \mathrm{kg}$ of DM, respectively (Williams et al., 2011; Pryce et al., 2015).

Table 1. Constants, conversion factors, and industry parameters based on an Australian herd of average genetic merit used to estimate base emissions, product output, changes in gross emissions due to each trait, and changes in emission intensity

\begin{tabular}{lr}
\hline Parameter & Value \\
\hline Production $^{1}$ & \\
Milk yield, kg & $6,861.00$ \\
Fat, \% & 4.00 \\
Protein, \% & 3.30 \\
Lactose, \% & 4.80 \\
Feed required & \\
Heifer, kg of DM & $3,526.76$ \\
Cow, kg of DM & $7,207.58$ \\
BW, ${ }^{2}$ kg & 600.00 \\
Herd proportion $^{1}$ & 27.00 \\
First parity, \% & 22.00 \\
Second parity, \% & 51.00 \\
Third parity, \% $^{2} \mathrm{CH}_{4}$ yield, ${ }^{3}$ kg/kg of DMI & 19.00 \\
$\mathrm{CH}_{4}$ global warming potential & \\
\hline
\end{tabular}

${ }^{1}$ Values obtained from DataGene Ltd. (2017).

${ }^{2}$ Williams et al. (2011) and Pryce et al. (2015).

${ }^{3}$ Richardson et al. (2021b).

${ }^{4}$ UNFCCC (2016). 


\section{Traits Under Investigation}

The Australian national selection index, the Balanced Performance Index (BPI), was released in 2016. Details of the index development are given by Byrne et al. (2016). The policy in Australia is for the national selection index to be updated periodically (every 5 yr). Based on the work of Zhang et al. (2019) and Bell et al. (2013), the traits previously determined to have an impact on emissions are production traits (milk, fat, and protein), fertility, survival, health, and feed efficiency.

\section{Methane Coefficient for Carbon Dioxide Equivalents}

The methane coefficient, defined as the environmental impact of $\mathrm{CH}_{4}$ per unit of feed, was derived from the Australian methane production to DMI ratio previously calculated (19.00 g of $\mathrm{CH}_{4} / \mathrm{kg}$ of DM; Richardson et al. 2021b) and from the global warming potential $(\mathbf{G W P})$ of $\mathrm{CH}_{4}\left(28.00 \mathrm{~kg}\right.$ of $\mathrm{CH}_{4} / \mathrm{kg}$ of $\mathrm{CO}_{2}$-eq; Gerber et al., 2013). The methane coefficient, expressed in $\mathrm{CO}_{2}$ equivalents $\left(\mathbf{C O}_{2} \mathbf{e}\right)$ was determined to be 0.532 $\mathrm{kg}$ of $\mathrm{CO}_{2}-\mathrm{eq} / \mathrm{kg}$ of $\mathrm{DM}\left(19.0 \mathrm{~g}\right.$ of $\mathrm{CH}_{4} / \mathrm{kg}$ of $\mathrm{DM} \times$ $28 \mathrm{~g}$ of $\mathrm{CH}_{4} / \mathrm{g}$ of $\mathrm{CO}_{2}$-eq) The relationship between methane production and DMI was previously reported to be linear (Richardson et al., 2019). Methane emissions coefficients were calculated on the basis of gross $\mathrm{CH}_{4}$ per animal and $\mathrm{CH}_{4}$ intensity per unit of milk protein equivalents (protein-eq). Both of these $\mathrm{CH}_{4}$ trait definitions represent an important goal and possible future breeding objective for $\mathrm{CH}_{4}$. Defining a $\mathrm{CH}_{4}$ breeding objective is specific to the reduction goals of each system and possible considerations for each $\mathrm{CH}_{4}$ definition are further described in the discussion.

\section{Protein Conversion Factor of Product Classes}

In line with previously published studies (Zhang et al., 2019; Richardson et al., 2021a), the product classes considered in this study are milk and its components (fat and protein). Similar to the concept that GWP is used to convert methane into $\mathrm{CO}_{2}$ equivalents, protein-eq conversion factors, $k_{j}$, convert milk and its component traits into a single output, protein-eq. This allows for multiple product classes to be considered and evaluated, while maintaining a single product class for comparison. Protein-equivalent conversion factors were based on component values of $\$ 6.76, \$ 2.08$, and $-\$ 0.11$, for protein, fat, and milk, respectively (Byrne et al., 2016). The resulting conversion factors were determined to be $1.00,0.31$, and -0.02 for protein, fat, and milk, respectively. The protein-eq value for milk volume is constituted by the milk volume percentage of lactose
$(4.8 \%)$ to avoid double counting the value of milk fat and milk protein, when milk volume is increased.

\section{Gross Methane of the Average Dairy System}

Yearly gross $\mathrm{CH}_{4}$ emissions produced by an average Australian dairy breeding cow, before genetic gain, were estimated using the following equation:

$$
E=\sum_{i=1}^{c} n_{i} F_{i} \alpha Y_{i}
$$

where $E$ is the total gross $\mathrm{CH}_{4}$ emitted before genetic change per breeding cow across $c$ classes (replacement heifers and cows), $n_{i}$ is the number of animals in a given stock class $i$ per breeding female in the average Australian dairy herd, $\alpha$ is the methane carbon dioxide equivalent coefficient per $\mathrm{kg}$ of DMI $\left(0.532 \mathrm{~kg}\right.$ of $\mathrm{CO}_{2} /$ $\mathrm{kg}$ of DM), $F_{i}$ is the amount of feed (in $\mathrm{kg}$ of DM) per animal of the stock class $i$, and $Y_{i}$ is a binary indicator variable that takes a value of 1 or 0 depending on whether the class $i$ is considered in the total definition of $\mathrm{CH}_{4}$ emissions, respectively. In this case, the animal classes considered were dairy cows and replacement heifers as male calves have marginal value in the Australian dairy industry.

\section{System Gross Emissions}

Table 1 summarizes the parameters of an average Australian dairy herd, which were used to estimate $E$. The total gross emissions per cow, considering the average Australian dairy herd and only methane GHG emissions, is calculated as an aggregate of the emissions produced by the cow and the emissions produced by the replacement animals required on average per lactating cow to maintain the milking herd. The average herd replacement rate was defined as the proportion of first parity animals in the herd, which in Australia is currently approximately $27 \%$ (E. Ooi, Bundoora, VIC, Australia, personal communication). The feed requirement for each stock class was based on previous studies as described above (Williams et al., 2011; Pryce et al., 2015).

\section{Gross Emission Per Unit Change in Trait}

The independent effect of each trait on the gross emissions produced per animal due to genetic improvement $(\boldsymbol{G} \boldsymbol{V})$ can be described by the first derivative of the above equation, with respect to a 1-unit genetic improvement in each trait, such that 


$$
G V=\sum_{i=1}^{c} \alpha Y_{i}\left(\frac{\partial n_{i}(g)}{\partial g} F_{i}+\frac{\partial F_{i}(g)}{\partial g} n_{i}\right),
$$

where $\frac{\partial n_{i}(g)}{\partial g}$ is the change in number of animals as a function of a 1-unit change in genetic trait $g, \frac{\partial F_{i}(g)}{\partial g}$ is the change in feed intake ( $\mathrm{kg}$ of DM) as a function of a 1-unit change in $g$, and $\alpha, n_{i}, F_{i}$, and $Y_{i}$ are as described above.

\section{Change in Gross Emission Due to Genetics}

The emissions generated by a 1-unit increase in production traits (milk volume, fat, and protein) are assumed to be directly proportional to the feed required to increase each production trait by 1 unit. For fat and protein, the emissions generated were calculated as the $\mathrm{CH}_{4}$ associated with the additional feed intake required (Table 2) to support an additional $1 \mathrm{~kg}$ of fat $(6.00$ $\mathrm{kg}$ of $\mathrm{DM} \times 0.532 \mathrm{~kg}$ of $\mathrm{CO}_{2} \mathrm{e} / \mathrm{kg}$ of $\mathrm{DM}=3.19 \mathrm{~kg}$ of $\left.\mathrm{CO}_{2} \mathrm{e}\right)$ or protein $\left(3.70 \mathrm{~kg}\right.$ of DM $\times 0.532 \mathrm{~kg}$ of $\mathrm{CO}_{2} \mathrm{e} /$ $\mathrm{kg}$ of $\mathrm{DM}=1.97 \mathrm{~kg}$ of $\left.\mathrm{CO}_{2} \mathrm{e}\right)$. When considering the total feed energy required for a 1-unit increase in milk production, only the feed required to support the additional lactose production was considered. The basis of this analysis assumes that the trait under investigation changes 1 unit, whereas all other traits are held constant. By accounting for milk production through the fluid (or lactose) portion of milk, we capture the independent effect of each production trait and avoid double counting the effects of fat and protein, as milk volume is osmotically driven by lactose. Therefore, the emissions generated by a 1-unit increase in milk volume were $2.60 \mathrm{~kg}$ of $\mathrm{DM} \times 0.532 \mathrm{~kg}$ of $\mathrm{CO}_{2} \mathrm{e} / \mathrm{kg}$ of $\mathrm{DM} \times$ $4.80 \%$ lactose $=0.07 \mathrm{~kg}$ of $\mathrm{CO}_{2} \mathrm{e}$.

Survival has a dual effect on $\mathrm{CH}_{4}$ emissions. Improvements in survival change herd structure, as higher survival rates result in fewer replacements being required to maintain the milking herd. Therefore, increased survival rates reduce the feed requirements and emissions associated with rearing replacements. However, lowering in the replacement rates will in turn increase the average age of the herd and the feed energy required for milking, as later parity cows require more feed to sustain a higher production level than the first parity counterparts (Haile-Mariam et al., 2003). The expected change in replacement rate due to a $1 \%$ increase in survival was modeled in a base herd with an average replacement rate of $27 \%$ (E. Ooi, Bundoora, VIC, Australia, personal communication) and compared with a herd where the survival rate was improved by $1 \%$, using methods described in Zhang et al. (2019). The change in replacement rate per unit increase in survival was estimated as -0.0069 (Table 3 ) with the associated emissions of $-24.62 \mathrm{~kg}$ of $\mathrm{CO}_{2} \mathrm{e}(-0.0069 \times 3,526.76 \mathrm{~kg}$ of DM per replacement $\times 0.532 \mathrm{CO}_{2} \mathrm{e} / \mathrm{kg}$ of $\left.\mathrm{DM}\right)$. The change in feed required per unit change in survival was modeled (Zhang et al., 2019) as the difference in feed per day required to sustain the increased milk production of a herd with 1\% improved survival. The emissions associated with this increase in an average herd age was calculated as $8.55 \mathrm{~kg}$ of DM additional feed required $\times 0.532 \mathrm{CO}_{2} \mathrm{e} / \mathrm{kg}$ of DM $=4.55 \mathrm{~kg}$ of $\mathrm{CO}_{2} \mathrm{e}$.

Much of the change in $\mathrm{CH}_{4}$ due to fertility is directly related to survival, as poor fertility status is a major reason for culling (Workie et al., 2019). The increased survival rates generally observed with improved herd fertility are assumed to be largely captured by the

Table 2. Trait-specific effects of feed intake per stock class, number of animals in the stock class, and average feed energy produced per day

\begin{tabular}{|c|c|c|c|c|}
\hline \multirow[b]{2}{*}{ Item } & \multicolumn{2}{|c|}{$\frac{\partial n_{i}(g)}{\partial g} 1$} & \multicolumn{2}{|c|}{$\frac{\partial F_{i}(g)}{\partial g} 2$} \\
\hline & Replacement & Cow & Replacement & Cow \\
\hline $\begin{array}{l}\text { Milk protein, } \mathrm{kg} \\
\text { Milk fat, kg } \\
\text { Milk yield, L } \\
\text { Survival, \% } \\
\text { Fertility, \% } \\
\text { Feed saved, kg } \\
\text { Mastitis resistance, \% }\end{array}$ & -0.0069 & & & $\begin{aligned} & 3.70 \\
& 6.00 \\
& 0.066 \\
& 8.55 \\
& 6.08 \\
&-1.00 \\
& 0.00\end{aligned}$ \\
\hline $\begin{array}{l}1 \frac{\partial n_{i}(g)}{\partial g} \text { is the change i } \\
2 \frac{\partial F_{i}(g)}{\partial g} \text { is the change } \mathrm{i}\end{array}$ & mals per unit & e in ea & & \\
\hline
\end{tabular}


Table 3. Genetic trends of index traits with an effect on dairy industry emissions

\begin{tabular}{lc}
\hline Trait & 5-yr annual genetic trend $^{1}$ \\
\hline Milk protein, kg & 6.5 \\
Milk fat, kg & 9.25 \\
Milk volume, L & 121.29 \\
Survival, \% & 2.09 \\
Fertility, \% & 0.82 \\
Feed saved, kg & 4.49 \\
Mastitis resistance, \% & 0.16 \\
\hline
\end{tabular}

${ }^{1}$ Provided by DataGene Ltd. (Bundoora).

survival EBV. However, fertility also has a direct effect on emissions. In Australia, approximately 35\% of herds practice seasonal calving (Byrne et al., 2016), a system that is defined by a clearly defined mating season, which results in large numbers of cows calving in a short period of time to match peak herd energy requirements with maximum pasture availability. In this system, improved fertility results in cows calving earlier in the season and therefore having a longer lactation than cows that calve later. This in turn results in a higher feed requirement and higher emissions. The emissions produced due to a change in fertility were calculated as the additional feed required to maintain milk production during the extended lactation, where the additional production days associated with a $1 \%$ increase in fertility was modeled as $0.9985 \mathrm{~d}$ (Zhang et al., 2019). Therefore, the emissions associated with a 1-unit change in fertility are $0.9985 \mathrm{~d} \times 17.37 \mathrm{~kg}$ of DM $\times 35 \%$ seasonal calving herds $\times 0.532 \mathrm{~kg}$ of $\mathrm{CO}_{2} \mathrm{e} / \mathrm{kg}$ of $\mathrm{DM}=3.24 \mathrm{~kg}$ of $\mathrm{CO}_{2} \mathrm{e}$.

Feed saved is the Australian feed efficiency trait that consists of a lifetime residual feed intake, genomic EBV, and BW EBV (Pryce et al., 2015). Feed saved is calculated by subtracting the animal's residual feed intake from the feed required to maintain $1 \mathrm{~kg}$ of extra BW and expressed so that a larger value represents a more efficient animals due to the lower maintenance costs of lesser-weight cows. Animals that are either not Holstein or not genotyped have their feed saved EBV approximated by BW only. The emissions associated with a 1-unit change in feed saved is the emissions generated by the 1-unit difference in feed intake $(1 \mathrm{~kg}$ of $\mathrm{DM} \times 0.532 \mathrm{~kg}$ of $\mathrm{CO}_{2}-\mathrm{eq} / \mathrm{kg}$ of $\left.\mathrm{DM}\right)$.

It is expected that a direct $\mathrm{CH}_{4}$ trait will become available in the future (Manzanilla-Pech et al., 2021; Richardson et al., 2021b). In Australia, a residual methane trait that corrects for production and intake has been developed (Richardson et al., 2021b). The emissions associated with a 1-unit increase in a residual methane trait is equivalent to the $\mathrm{CO}_{2}$ e produced by a 1-unit increase in $\mathrm{CH}_{4}$ (1 kg of methane $\times 28 \mathrm{GWP}=$
$28 \mathrm{~kg}$ of $\mathrm{CO}_{2} \mathrm{e}$ ), assuming that the trait is defined as a $1-\mathrm{kg}$ decrease in residual methane per lactation.

\section{Emission Intensity of the Average Dairy System}

The per cow environmental impact can also be expressed through emissions intensity, which is defined as the total gross emissions generated, $E$, divided by the total number of product output equivalents per cow $(\boldsymbol{M})$. In this scenario, product outputs are expressed in protein-eq and all other product classes are converted to protein-eq based on value ratios. Total product output, in protein-eq, before genetic change was calculated as follows:

$$
M=\sum_{j=1}^{p} k_{j} \sum_{i=1}^{c} n_{i j} m_{i j} X_{i j},
$$

where $M$ is the total product output, expressed in protein-eq, produced per breeding cow across all product classes, $p$, included in the product definition objective, before genetic change, $n_{i j}$ is the number of animals per breeding female (specific to both stock class $i$ and product type $j$ ), $m_{i j}$ is the product output per animal in product type $j, X_{i j}$ is the indicator variable that takes a value of either 1 or 0 depending on whether type $j$ should be considered in the total definition of product output, and $k_{j}$ is the protein equivalent conversion factor. Therefore, the emission intensity $(\boldsymbol{E I})$ per animal product, before genetic change, is

$$
E I=\frac{E}{M}=\frac{\sum_{i=1}^{c} n_{i} F_{i} \alpha_{i} Y_{i}}{\sum_{j=1}^{p} k_{j} \sum_{i=1}^{c} n_{i j} m_{i j} X_{i j}} .
$$

\section{Emission Intensity Per Unit Change in Trait}

The independent effect of each trait on EI due to genetic improvement can be determined using methods adapted from Amer et al. (2018). By taking the first derivative of Equation 4 with respect to a 1-unit genetic improvement of each trait, the change in $E I$ due to a unit change in each trait, termed intensity value $(\boldsymbol{I} \boldsymbol{V})$, is described as

$$
I V=\frac{1}{M}\left\{\begin{array}{l}
\sum_{i=1}^{c} \alpha_{i} Y_{i}\left(\frac{\partial n_{i}(g)}{\partial g} F_{i}+\frac{\partial F_{i}(g)}{\partial g} n_{i}\right) \\
-E I \sum_{j=1}^{p} k_{j}\left(\frac{\partial n_{i j}(g)}{\partial g} m_{i j}+\frac{\partial m_{i j}(g)}{\partial g} n_{i j}\right)
\end{array}\right\}, \quad[5]
$$


Table 4. Trait-specific change in animal product, $j$, as a function of change in trait, $g$

\begin{tabular}{|c|c|c|c|}
\hline \multirow[b]{2}{*}{ Item } & \multicolumn{3}{|c|}{${\frac{\partial m_{i j}(g)}{\partial g}}_{1}$} \\
\hline & $\begin{array}{c}\text { Milk } \\
\text { protein }\end{array}$ & $\begin{array}{l}\text { Milk } \\
\text { fat }\end{array}$ & $\begin{array}{l}\text { Milk } \\
\text { yield }\end{array}$ \\
\hline Milk protein, $\mathrm{kg}$ & 1.00 & & \\
\hline Milk fat, $\mathrm{kg}$ & & 1.00 & \\
\hline Milk yield, L & & & 1.00 \\
\hline Survival, \% & 0.25 & 0.20 & 3.66 \\
\hline Fertility, \% & 0.21 & 0.17 & 4.87 \\
\hline Feed saved, kg & & & \\
\hline Mastitis resistance, \% & 0.17 & 0.14 & 2.53 \\
\hline
\end{tabular}

where $\frac{\partial m_{i j}(g)}{\partial g}$ is the change in the animal product, $j$, per unit change in a genetic trait for stock class $i$, and all other variables are as previously described.

\section{Change in Product Output Due to Genetics}

The product output for production traits (milk, fat, protein) is directly equivalent to the protein-eq for a 1-unit improvement in the production trait under investigation. Therefore, the change in product output associated with each trait is the 1-unit change in the trait converted into protein-eq (Table 4 ). The product output was calculated as $-0.02 \mathrm{~kg}$ of protein-eq for milk volume, $0.31 \mathrm{~kg}$ of protein-eq for fat, and $1 \mathrm{~kg}$ of protein-eq for protein.

A change in survival affects product output as a decrease in replacement rate translates to an older average herd with higher milk production, because later parity animals generally produce more than first parity animals. Therefore, the change in product output due to genetic gain in survival is the increased production expected from a herd where survival has increased by
$1 \%$. This change in product output associated with a 1-unit increase in survival was modeled as described by Zhang et al. (2019), where production of a base herd was compared with an improved-survival herd.

As survival accounts for the product output associated with changes in herd structure, the independent effect of improved fertility on product output is the additional production associated with extended lactation in seasonal calving systems. Therefore, the change in production due to fertility is the additional days of lactation due to a $1 \%$ increase in fertility $(0.99 \mathrm{~d}$; modeled as Zhang et al., 2019) $\times$ the proportion of Australian herds following a seasonal calving pattern $(35 \%) \times$ the average daily production at the end of lactation (12.5 $\mathrm{kg}$ of milk; Abdelsayed et al., 2015), converted into protein-eq based on the assumed percentage composition of each milk component (4.0\% fat and $3.30 \%$ protein).

Mastitis resistance (MR) affects product output as higher MR EBV relates to lower cases of mastitis and less milk dumped due to mastitis treatment protocols. The change in product output due to MR is equivalent to the discarded milk not recovered for calf feeding (8.13 kg of milk solids; Byrne et al., 2016) $\times$ the clinical mastitis incident rate per unit change in MR (0.03; G. Nieuwhof, Bundoora, VIC, Australia, personal communication $) \times$ the number of treatments per incident $(1.20$; Byrne et al., 2016), converted into protein equivalents based on the assumed percentage composition of each milk component (4.0\% fat and $3.30 \%$ protein).

\section{Annual Emissions Response}

To put the $G V$ and $I V$ coefficients into perspective, the annual expected $\mathrm{CO}_{2} \mathrm{e}$ change in gross emissions and emissions intensity was estimated (Table 5). The $G V$ and $I V$ coefficients estimated for each trait were multiplied by the respective 5 -yr average annual trait genetic trends (Table 2). Genetic trends were supplied by DataGene Ltd. and expected to be representative of the Australian dairy response to selection.

Table 5. Change in gross emissions and emissions intensity due to a unit change in each trait and expected annual change due to each trait ${ }^{1}$

\begin{tabular}{lccrr}
\hline Trait & $\begin{array}{c}G V, \mathrm{~kg} \text { of } \mathrm{CO}_{2} \mathrm{e} / \\
\text { unit trait }\end{array}$ & $\begin{array}{c}\text { Expected annual } \\
\text { change in kg of } \mathrm{CO}_{2} \mathrm{e}^{2}\end{array}$ & $\begin{array}{c}I V, \mathrm{~kg} \text { of } \mathrm{CO}_{2} \mathrm{e} / \mathrm{kg} \\
\text { protein-eq }\end{array}$ & $\begin{array}{c}\text { Expected annual change } \\
\text { in } \mathrm{CO}_{2} \mathrm{e} / \mathrm{kg} \text { of protein-eq }\end{array}$ \\
\hline Milk protein, kg & 1.97 & 12.79 & -0.032 & -0.205 \\
Milk fat, kg & 3.19 & 29.52 & -0.002 & -0.020 \\
Milk volume, $\mathrm{L}$ & 0.04 & -1.27 & 0.001 & 0.086 \\
Survival, \% & -8.55 & -17.88 & -0.035 & -0.070 \\
Fertility, \% & 3.24 & 2.65 & 0.004 & 0.003 \\
Feed saved, kg & -0.53 & -2.39 & -0.002 & -0.007 \\
Mastitis resistance, $\%$ & 0.00 & 0.00 & 0.006 & -0.001 \\
\hline
\end{tabular}

${ }^{1} \mathrm{CO}_{2} \mathrm{e}=\mathrm{CO}_{2}$ equivalents; protein-eq = protein equivalents; $G V=$ genetic improvement; $I V=$ intensity value.

${ }^{2}$ Calculated using genetic trends supplied in Table 2 and provided by DataGene Ltd. 


\section{Sensitivity Analysis}

A sensitivity analysis was performed to account for the variation in product value ratio and feeding systems in Australia, which contribute to the total product output and methane coefficient, respectively. The value of fat relative to protein varies throughout and between financial years and different countries assume substantially different relative prices for fat in their national selection indexes (Miglior et al., 2017). To demonstrate the effects of this value ratio on $M$ and $E I$, protein-eq conversion factors were tested at fat to protein ratios of $0.2,0.95$, and 1.25 . When testing the sensitivity of modeled outcomes to the relative values of milk fat to milk protein (parameter $k_{f a t}$ ), we simultaneously manipulated the assigned value of protein to keep a constant overall milk return to the farmer and avoid artificially inflating the value of the milk components. There are 5 feeding systems actively used in Australia, each with a varying level of forage to concentrate ratio, affecting the subsequent methane coefficient $\left(\mathrm{kg}\right.$ of $\mathrm{CH}_{4} / \mathrm{kg}$ of DMI). To account for this, a high and low methane coefficient was used to stress the system at $\pm 5 \%, 10 \%$, and $20 \%$.

\section{RESULTS}

\section{System Emissions Without Genetic Change}

Based on an average Australian dairy herd, the gross emissions emitted per breeding cow were $4,297.86 \mathrm{~kg}$ of $\mathrm{CO}_{2}$-eq per year. The annual product output and emissions intensity per breeding cow were $339.29 \mathrm{~kg}$ of protein-eq and $12.67 \mathrm{~kg}$ of $\mathrm{CO}_{2}$-eq $/ \mathrm{kg}$ of protein-eq, respectively.

\section{Change in Gross Emissions Attributed to Genetics}

Results are presented in Table 5, with values for intermediate calculations for changes in herd structure and feed requirements presented in Table 3. When considering the change in gross emission associated with a unit change in each trait, survival $(-8.55 \mathrm{~kg}$ of $\mathrm{CO}_{2}$-eq) had the most favorable $G V$ with feed saved $\left(-0.53 \mathrm{CO}_{2}\right.$-eq) being the only other trait that lowered emissions. Milk, fat, and protein had unfavorable $G V$ of $0.04,3.19$, and $1.97 \mathrm{~kg}$ of $\mathrm{CO}_{2}$-eq, respectively, and fertility had the largest unfavorable effect of $3.24 \mathrm{~kg}$ of $\mathrm{CO}_{2}$-eq $\mathrm{kg}$ of $\mathrm{CO}_{2}$-eq.

To estimate the expected change in emissions related to each trait relevant to the expected response to selection, each $G V$ was multiplied by its respective 5 -yr annual genetic trend (Table 2). Under this perspective (Table 5), survival and feed saved had the most favor- able environmental impacts $(-17.88$ and $-2.39 \mathrm{~kg}$ of $\mathrm{CO}_{2}$-eq/year, respectively). Fertility, milk volume, and milk protein had unfavorable environmental impacts of $2.65,4.27$, and $12.79 \mathrm{~kg}$ of $\mathrm{CO}_{2}$-eq/year. The largest unfavorable annual change in emissions was due to milk fat at $29.53 \mathrm{~kg}$ of $\mathrm{CO}_{2}$-eq/year.

\section{Change in Emissions Intensity Attributed to Genetics}

Results are presented in Table 5, with values for intermediate calculations for changes in gross emissions and product outputs presented in Tables 3 and 4 , respectively. Without considering the magnitude of the annual genetic improvement of each trait, survival $\left(-0.034 \mathrm{~kg}\right.$ of $\mathrm{CO}_{2}$-eq $/ \mathrm{kg}$ of protein-eq) had the most favorable EV. Milk protein $\left(-0.032 \quad \mathrm{CO}_{2}\right.$-eq/ $\mathrm{kg}$ of protein-eq) had the second largest favorable effect with $\mathrm{MR}$ having a moderate favorable effect of $-0.006 \mathrm{CO}_{2^{-}}$ eq $/ \mathrm{kg}$ of protein-eq. Fat and feed saved also lowering emissions intensity, both with the smallest favorable EV of $-0.002 \mathrm{CO}_{2}$-eq $/ \mathrm{kg}$ of protein-eq (Table 5). Contrastingly, fertility and milk yield had unfavorable effects of 0.004 and $0.001 \mathrm{CO}_{2}-\mathrm{eq} / \mathrm{kg}$ of protein-eq, respectively.

Multiplying the 5-yr annual genetic trend by each trait $E I$ value, the expected annual change in emissions intensity related to each trait was presented in Table 5. Under this perspective, milk protein and survival had the most favorable environmental impacts $(-0.21$ and $-0.07 \mathrm{~kg}$ of $\mathrm{CO}_{2}$-eq $/ \mathrm{kg}$ of protein-eq per year, respectively). Additionally, milk fat and feed saved had favorable annual reductions in EI of -0.02 and -0.007 $\mathrm{CO}_{2}$-eq $/ \mathrm{kg}$ of protein-eq per year, respectively. Fertility and MR had very minimal effects on $E I$ with annual $I V$ of 0.002 and $0.001 \mathrm{~kg}$ of $\mathrm{CO}_{2}$-eq/ $\mathrm{kg}$ of protein-eq per year, respectively.

\section{Sensitivity Analysis}

The effects of changing fat to protein ratio values as well as variations in methane coefficients on $E, M$, and EI are presented in Table 6. The EI calculated under the protein-eq conversion ratios, which represent the 2-extreme scenarios $(0.20$ and 1.25$)$, were 12.50 $\mathrm{CO}_{2}$-eq/kg of protein-eq per year and $10.03 \mathrm{CO}_{2}$-eq/ $\mathrm{kg}$ of protein-eq per year, respectively. However, the emissions per $\mathrm{kg}$ of protein-eq compared with the base estimation of $E I\left(12.67 \mathrm{CO}_{2}\right.$-eq/ $\mathrm{kg}$ of protein-eq per year) varied by only $0.0025 \%$ when the protein-eq conversion ratio was increased to 0.95 , in agreement with the current global trend. As the fat to protein value ratio approaches 1.00 , the value of fat more becomes more equivalent to protein and the $I V$ for fertility becomes negligible due to the increased product output being realized. The change in $E$ and $E I$ was directly 
Table 6. Sensitivity analysis accounting for the variation in product value ratio and feeding systems in Australia, where protein-equivalent conversion factors were stressed at a fat to protein value ratio $\left(k_{\text {fat }}\right)$ of 0.2 , 0.95 , and 1.25 , and a high and low methane coefficient was used to stress the system at $\pm 5 \%, 10 \%$, and $20 \%$

\begin{tabular}{lcccc}
\hline Item & Base $\left(k_{\text {fat }}=0.31\right)$ & $k_{\text {fat }}=0.20$ & $k_{\text {fat }}=0.95$ & $k_{\text {fat }}=1.25$ \\
\hline$E^{\mathrm{l}}$ & $4,297.86$ & $4,297.86$ & $4,297.86$ & $4,297.86$ \\
$M^{2}$ & 339.29 & 343.75 & 385.40 & 428.62 \\
$E I^{3}$ & 12.67 & 12.50 & 11.15 & 10.03 \\
& Base & $+5 \%$ & $+10 \%$ & $+20 \%$ \\
$E$ & $4,297.86$ & $4,512.76$ & $4,964.03$ & $5,157.44$ \\
$M$ & 339.29 & 339.29 & 339.29 & 339.29 \\
$E I$ & 12.67 & 13.30 & 14.63 & 15.20 \\
& Base & $-5 \%$ & $-10 \%$ & $-20 \%$ \\
$E$ & $4,297.86$ & $4,082.97$ & $3,868.08$ & $3,438.29$ \\
$M$ & 339.29 & 339.29 & 339.29 & 339.29 \\
$E I$ & 12.67 & 12.03 & 11.40 & 10.13 \\
\hline
\end{tabular}

${ }^{1} E$ is the total gross methane emitted before genetic change per breeding.

${ }^{2} M$ is the total product output, expressed in protein-equivalents, produced per breeding.

${ }^{3} E I$ is the emission intensity before genetic change.

proportional to the $\pm 5 \%, 10 \%$, or $20 \%$ change in the methane coefficient when compared with the base.

\section{DISCUSSION}

The aim of this research was to calculate coefficients that describe the change in methane attributed to traits under selection in Australian dairy cattle in gross methane and methane intensity. Our results estimate gross emissions per breeding cow of $4,297.86 \mathrm{~kg}$ and an emissions intensity of $12.67 \mathrm{~kg}$ of $\mathrm{CH}_{4} / \mathrm{kg}$ of protein-eq, and consistently showed the importance of selection for survival, production, and efficiency through the estimated coefficients. Using the gross methane per breeding cow value estimated in our study, we estimated a national inventory due to dairy cattle methane of $6.02 \mathrm{Mt}$ of $\mathrm{CO}_{2} \mathrm{e}$, assuming that the Australian dairy cattle inventory was 1.4 million milking and dry cows (Newton et al., 2020). These values are reasonably consistent with the current Australian national emissions inventory for the dairy industry of $8.6224 \mathrm{Mt}$ of $\mathrm{CO}_{2} \mathrm{e}$ (UNFCCC, 2018), of which methane constitutes approximately $57 \%$ at $4.914 \mathrm{Mt}$ of $\mathrm{CO}_{2} \mathrm{e}$.

\section{Indirect Methods to Reduce Emissions}

The BPI is the national dairy cow selection index in Australia (Byrne et al., 2016) and includes traits that contribute to profitability including production, survival, fertility, MR, and feed efficiency. Currently the index does not include methane directly, but it does include traits such as longevity and feed saved that, as we have shown in the present study, can have a favorable effect on methane emissions.

As suggested by Wall et al. (2010), there are 3 possible opportunities to reduce emissions per unit of prod- uct through genetic selection: (1) a direct $\mathrm{CH}_{4}$ trait, (2) a reduction in replacements, and (3) an increase in product output per animal. However, opportunities 1 and 2 may also be applied to reduce gross emissions. In this paper we explored options that did not require a direct $\mathrm{CH}_{4}$ trait, but rather relied on existing EBV. Consistent with Wall et al. (2010), our results imply that reducing replacements through selection for longevity and fertility and increasing production efficiency through feed saved may be effective strategies to reduce gross emissions and emissions intensity. Additionally, the dilution effect of product output achieved through gains in production traits and MR may also be effective in reducing emissions intensity. However, unless the increase in production output results in fewer overall animals, such as is the case with supply management (Richardson et al., 2021a), the effect may not be environmentally beneficial. As the rate of genetic gain in production traits is increasing (Cole et al., 2020), so is the feed requirement and gross emissions. This trend is likely to mean that while $\mathrm{CH}_{4}$ intensity is decreasing, gross emissions are increasing, consistent with the unfavorable gross emissions environmental weights for production traits estimated in our study.

\section{Independent Trait Effects}

Of the traits included in the Australian NBO, genetic progress in survival and feed saved were consistently shown to result in a favorable environmental impact. Conversely, production traits had an unfavorable environmental impact when considering gross emissions, and favorable when considering emissions intensity. These conflicting results were expected as genetic gain in production traits will lead to high yielding cows with increased feed requirement, resulting in higher 
gross emissions and an unfavorable environmental impact. However, when methane intensity is considered, the negative effect of increased feed requirement is overbalanced by the product output of milk and its components, resulting in a favorable environmental impact when the number of animals is reduced. A key assumption of the present study is that the independent effect of each trait is estimated, while all other traits remain static, to avoid double counting. For example, if changes in milk production were to be accounted for through ECM, then we would be assuming that fat and protein are increasing proportionally to the milk BV, contrasting to our model assumptions and resulting in double counting.

The challenge of calculating the independent effect of each trait, when the change in emissions cannot be isolated to a single trait, is also observed in traits with an effect on herd structure. Survival and fertility are intertwined at the management level, creating challenges when calculating the effect of each trait independently. Improved fertility at the herd level has a positive effect on the environment. However, this is primarily due to higher survival rates and the requirement of fewer heifers, which is captured through the survival BV. In the case of fertility and survival, a 1-unit increase in either trait results in a reduction of emissions through a change in herd structure, as fewer replacements are required. Additionally, in the case of emissions intensity, an older herd will have a higher production level, and therefore lower emissions intensity. As fertility is a primary reason for culling, the effects of the 2 traits are confounded (Workie et al., 2019). To avoid double counting, we attributed these effects solely to survival. This confounding factor may be overcome by using a survival trait that accounts for voluntary culling, such as herd life (Richardson et al., 2021a) or residual survival (Zhang et al., 2019). This is shown in New Zealand where the survival is represented through residual survival, a survival trait that is independent of fertility. In Zhang et al. (2019), the positive impacts of replacement reductions could be attributed to each trait separately.

\section{Sensitivity Analysis}

Similar to Zhang et al. (2019), our results showed that varying the protein to fat value ratio influences $E I$ through the protein-eq value and concluded that increasing the protein-eq value ratio reduced $E I$ through increasing $M$. Thus, changing the protein-eq value changes the magnitude of the milk protein equivalent units, but not the overall trend in $E I$ due to genetic gain. The exception to this is fertility as the effect of the fertility $I V$ on $E I$ became negligible with more equivalent values of fat to protein. This change is due to the trait definition of fertility used in the current study. As the change in herd structure due to fertility is accounted for by the survival EBV, only the change in production due to extended lactation is captured by fertility. Therefore, the fertility $I V$ is affected by the change in the protein-eq ratio value. However, the overall effect of the fertility $I V$ on $E I$ is minimal and therefore does not strongly affect the overall trend.

\section{Comparison to International Studies}

Using adapted methods of the approach proposed by Amer et al. (2018), production, survival, and fertility were identified as key traits to reduce emissions in the New Zealand dairy (Zhang et al., 2019), Canadian dairy (Richardson et al., 2021a), and Irish dairy and beef (Amer et al., 2018; Quinton et al., 2018) industries. These industry cases differ in breeding objective, feeding system, housing system, and product output; however, the traits identified as having the largest environmental impact were consistent.

Bell et al. (2013) used a bio-economic model to investigate the environmental impact of Australian dairy traits. While they included nitrogen output and manure management in addition to methane, our results are remarkably similar. It is noteworthy that the weights developed in our study account for relationships between traits and therefore could be applied to EBV to estimate methane emissions, whereas those of Bell et al. (2013) were not designed to do this. This is particularly evident in the fertility and survival values, which is further discussed below.

\section{Application of Gross and Intensity Weights}

Genetics is an option that offers a permanent solution to reduce emissions and there are several strategies that can be simplistically incorporated in breeding programs to target a reduction in emissions, one of which is the application of environmental weights. Gross methane weights and methane intensity weights are 2 definitions of emission coefficients that quantify the effect of current traits on the environment. These weights may be used in selection indexes to apply emphasis on traits based on their environmental impact.

In terms of breeding objectives, gross $\mathrm{CH}_{4}$ production is currently the metric used by the Intergovernmental Panel on Climate Change in the Paris Agreement to estimate and report national GHG inventories on a global scale. Using gross $\mathrm{CH}_{4}$ coefficients in selection indexes allows for the changes in methane achieved through genetic selection to be clearly conceptualized by many stakeholders, such as researchers, dairy producers, and 
government. Gross $\mathrm{CH}_{4}$ is a linear trait definition with a conceptually clear response to selection as it represents the direct, independent change in methane associated with each index trait. However, considering gross emissions does not take into consideration that for some industries, such as the dairy industry, we require the industry to continue to grow, thereby increasing the challenge to reduce emissions at an industry level.

Methane intensity coefficients are designed to estimate the environmental productivity of traits, when considering both product output and the environment. This EBV has the benefit of ensuring the industry remains sustainably productive, leaning toward a more net neutral system. However, methane intensity is a ratio trait and the response to selection associated with its component traits (gross emissions and product output) are more challenging to attribute. It is unclear whether a reduction in methane intensity due to genetic improvements is from a decrease in gross emissions or a dilution effect through increases in production, which unless animal numbers decrease as a result (such as with supply management in Canada), is not environmentally advantageous.

The development of future indexes should consider the possible environmental responsibilities of farmers. A major factor for continual genetic improvement is the index adoption rate by farmers. Methane intensity coefficients may be more appealing to farmers as the estimated coefficients do not penalize high (solids) producing cows; however, if the industry is required to reduce net emissions, a gross methane coefficient may be more favorable as genetic progress is conceptually clear and a direct reduction is simple to report.

\section{Inventory Application of Methane Coefficients}

The results from this study can be used by geneticists and stakeholders. For geneticists, the weights could be used to develop indexes that farmers can apply to select for reduced methane emissions, whereas for other stakeholders, such as government, the weights could be used to capture the genetic and phenotypic changes in methane emissions over time, offering an additional use for these weights. Due to the limitation of methane data collection on-farm, it is challenging to estimate emissions at the farm or individual animal level. These coefficients can be applied to the EBV of an individual animal or the farm average genetic gain to more accurately estimate current GHG inventories, as more of the variation between animals is captured compared with current Intergovernmental Panel on Climate Change methods. This method may also be applied to other GHG or product outputs to calculate coefficient that would allow for a more robust inventory estimate to be made. This may assist stakeholders or governments to trace farm-specific methane emissions, instead of using simplistic methods that count the number of cows, and assume constant emissions per cow both across farms, and over time. The method used in our study requires minimal inputs and less computational complexity to estimate a cow-specific emissions value and may improve long-term tracing of changes in dairy industry methane emissions.

\section{Future Strategies}

This method offers one strategy to reduce emissions; another is by selecting for a direct $\mathrm{CH}_{4}$ trait. Many studies have aimed to define the optimal $\mathrm{CH}_{4}$ trait to select for lower emissions. However, the trait definitions currently proposed for inclusion in a breeding program are not adequate as they are derived from small data sets and challenging to predict accurately. Previous studies aimed at predicting EBV for expensive or difficult to measure traits, such as DMI (Berry et al., 2014), have successfully increased data set size by combining data sets internationally. Methane introduces new challenges when implementing this approach as the analysis relies on many small data sets using different measurement techniques, introducing additional error. As methane for each country must be considered an independent trait, multitrait models are used which increases computational complexity (Manzanilla-Pech, 2021).

It is expected that a direct $\mathrm{CH}_{4} \mathrm{EBV}$ may become available in the near future (Manzanilla-Pech et al., 2021; Richardson et al., 2021b). In Australia, a residual methane trait that corrects for production and intake is most likely to be implemented (Richardson et al., 2021b). However, due to the limitation of data ( $\mathrm{n}=$ 420, Richardson et al., 2021a) and challenges associated with combining data sets (Manzanilla-Pech et al., 2021), it is expected that the accuracy of genomic predictions will be low (González-Recio et al., 2020). Therefore, the optimal method to reduce emissions may be to develop a subindex comprised of a direct methane trait and the traits shown to have the largest effect on emissions, weighted using the coefficients estimated in the current study.

\section{CONCLUSIONS}

This paper describes estimated methane coefficients that describe the expected change in methane per unit change in each trait, defined in gross emission and emissions intensity. Of the traits included in the Australian NBO, genetic progress in survival and feed saved were consistently shown to result in a favorable environmental impact. Conversely, production traits had an unfa- 
vorable environmental impact when considering gross emissions, and favorable when considering emissions intensity. Fertility had minimal effect as its effects were primarily accounted for though survival, with MR only affecting $E I$ coefficients. These coefficients may be used in selection indexes to apply emphasis on traits based on their environmental impact, as well as applied by government and stakeholders to track trends in industry emissions. Although current initiatives are underway to develop EBV for methane by combining small methane data sets internationally, they are hampered by small numbers and different ways of measuring methane. Therefore, alternative options to reduce emissions by utilizing selection indexes should be further explored.

\section{ACKNOWLEDGMENTS}

We thank DairyBio, jointly funded by Dairy Australia (Melbourne, Australia), The Gardiner Foundation (Melbourne, Australia), and Agriculture Victoria (Melbourne, Australia), for funding this project and C.M. Richardson's PhD project. Special thanks go to Tim Luke, Peter Moate, and other colleagues from Agriculture Victoria Research (Bundoora, Victoria, Australia) and the University of Guelph (Guelph, ON, Canada) for useful discussions that have helped to shape the thinking in this paper. The authors have not stated any conflicts of interest.

\section{REFERENCES}

Abdelsayed, M., P. C. Thomson, and H. W. Raadsma. 2015. A review of the genetic and non-genetic factors affecting extended lactation in pasture-based dairy systems. Anim. Prod. Sci. 55:949-966. https://doi.org/10.1071/AN13300.

Amer, P. R., F. S. Hely, C. D. Quinton, and A. R. Cromie. 2018. A methodology framework for weighting genetic traits that impact greenhouse gas emissions intensity into selection indexes. Animal 12:5-11. https://doi.org/10.1017/S1751731117001549.

Appuhamy, J. A., J. France, and E. Kebreab. 2016. Models for predicting enteric methane emissions from dairy cows in North America, Europe, and Australia and New Zealand. Glob. Change Biol. 22:3039-3056. https://doi.org/10.1111/gcb.13339.

Basarab, J. A., K. A. Beauchemin, V. S. Baron, K. H. Ominski, L. L. Guan, S. P. Miller, and J. J. Crowley. 2013. Reducing GHG emissions through genetic improvement for feed efficiency: Effects on economically important traits and enteric methane production. Animal 7:303-315. https://doi.org/10.1017/S1751731113000888.

Bell, M. J., R. J. Eckard, M. Haile-Mariam, and J. E. Pryce. 2013. The effect of changing cow production and fitness traits on net income and greenhouse gas emissions from Australian dairy systems. J. Dairy Sci. 96:7918-7931. https://doi.org/10.3168/jds.2012-6289.

Berry, D. P., M. P. Coffey, J. E. Pryce, Y. de Haas, P. Løvendahl, N. Krattenmacher, J. J. Crowley, Z. Wang, D. Spurlock, K. Weigel, K. Macdonald, and R. F. Veerkamp. 2014. International genetic evaluations for feed intake in dairy cattle through the collation of data from multiple sources. J. Dairy Sci. 97:3894-3905. https://doi .org/10.3168/jds.2013-7548.

Byrne, T. J., B. F. S. Santos, P. R. Amer, D. Martin-Collado, J. E. Pryce, and M. Axford. 2016. New breeding objectives and selection indices for the Australian dairy industry. J. Dairy Sci. 99:81468167. https://doi.org/10.3168/jds.2015-10747.

Cole, J. B., S. A. E. Eaglen, C. Maltecca, H. A. Mulder, and J. E. Pryce. 2020. The future of phenomics in dairy cattle breeding. Anim. Front. 10:37-44. https://doi.org/10.1093/af/vfaa007.

DataGene Ltd. 2017. Australian dairy herd improvement report. Accessed May 21, 2020. https://datagene.com.au/ct-menu-item-13/ industry-statistics?fid $=18$.

de Haas, Y., M. Pszczola, H. Soyeurt, E. Wall, and J. Lassen. 2017. Invited review: Phenotypes to genetically reduce greenhouse gas emissions in dairying. J. Dairy Sci. 100:855-870. https://doi.org/ $10.3168 / j d s .2016-11246$.

Difford, G. F., P. Løvendahl, R. F. Veerkamp, H. Bovenhuis, M. H. P. W. Visker, J. Lassen, and Y. de Haas. 2020. Can greenhouse gases in breath be used to genetically improve feed efficiency of dairy cows? J. Dairy Sci. 103:2442-2459. https://doi.org/10.3168/ jds.2019-16966.

Efficient Dairy Genome Project (EDGP). 2016. The Efficient Dairy Genome Project - An International Project. Accessed Nov. 3, 2020. https://genomedairy.ualberta.ca.

Ellis, J. L., J. Dijkstra, E. Kebreab, A. Bannink, N. E. Odongo, B. W. McBride, and J. France. 2008. Aspects of rumen microbiology central to mechanistic modelling of methane production in cattle. J. Agric. Sci. 146:213-233. https://doi.org/10.1017/ S0021859608007752.

EPA. 2020. Overview of Greenhouse Gases. Accessed May 7, 2020. https://www.epa.gov/ghgemissions/overview-greenhouse-gases \#methane.

FAO. 2013. Tackling climate change through livestock: A global assessment of emissions and mitigation opportunities. Accessed Jun. 24, 2021. http://www.fao.org/3/a-i3437e.pdf.

Flay, H. E., B. Kuhn-Sherlock, K. A. Macdonald, M. Camara, N. Lopez-Villalobos, D. J. Donaghy, and J. R. Roche. 2019. Hot topic: Selecting cattle for low residual feed intake did not affect daily methane production but increased methane yield. J. Dairy Sci. 102:2708-2713. https://doi.org/10.3168/jds.2018-15234.

Gerber, P. J., A. N. Hristov, B. Henderson, H. Makkar, J. Oh, C. Lee, R. Meinen, F. Montes, T. Ott, J. Firkins, A. Rotz, C. Dell, A. T. Adesogan, W. Z. Yang, J. M. Tricarico, E. Kebreab, G. Waghorn, J. Dijkstra, and S. Oosting. 2013. Technical options for the mitigation of direct methane and nitrous oxide emissions from livestock: A review. Animal 7:220-234. https://doi.org/10.1017/ S1751731113000876.

González-Recio, O., J. López-Paredes, L. Ouatahar, N. Charfeddine, E. Ugarte, R. Alenda, and J. A. Jiménez-Montero. 2020. Mitigation of greenhouse gases in dairy cattle via genetic selection: 2 . Incorporating methane emissions into the breeding goal. J. Dairy Sci. 103:7210-7221. https://doi.org/10.3168/jds.2019-17598.

Haile-Mariam, M., P. J. Bowman, and M. E. Goddard. 2003. Genetic and environmental relationship among calving interval, survival, persistency of milk yield and somatic cell count in dairy cattle. Livest. Prod. Sci. 80:189-200. https://doi.org/10.1016/S0301 -6226(02)00188-4.

Hristov, A. N., E. Kebreab, M. Niu, J. Oh, A. Bannink, A. R. Bayat, T. B. Boland, A. F. Brito, D. P. Casper, L. A. Crompton, J. Dijkstra, M. Eugène, P. C. Garnsworthy, N. Haque, A. L. F. Hellwing, P. Huhtanen, M. Kreuzer, B. Kuhla, P. Lund, J. Madsen, C. Martin, P. J. Moate, S. Muetzel, C. Muñoz, N. Peiren, J. M. Powell, C. K. Reynolds, A. Schwarm, K. J. Shingfield, T. M. Storlien, M. R. Weisbjerg, D. R. Yáñez-Ruiz, and Z. Yu. 2018. Symposium review: Uncertainties in enteric methane inventories, measurement techniques, and prediction models. J. Dairy Sci. 101:6655-6674. https://doi.org/10.3168/jds.2017-13536.

Jentsch, W., M. Schweigel, F. Weissbach, H. Scholze, W. Pitroff, and M. Derno. 2007. Methane production in cattle calculated by the nutrient composition of the diet. Arch. Anim. Nutr. 61:10-19. https://doi.org/10.1080/17450390601106580.

Løvendahl, P., G. F. Difford, B. Li, M. G. G. Chagunda, P. Huhtanen, M. H. Lidauer, J. Lassen, and P. Lund. 2018. Review: Selecting for improved feed efficiency and reduced methane emissions 
in dairy cattle. Animal 12:336-349. https://doi.org/10.1017/ S1751731118002276.

Manzanilla-Pech, C. I. V., P. Løvendahl, D. Mansan Gordo, G. F. Difford, J. E. Pryce, F. Schenkel, S. Wegmann, F. Miglior, T. C. Chud, P. J. Moate, S. R. O. Williams, C. M. Richardson, P. Stothard, and J. Lassen. 2021. Breeding for low methane emitting and feed efficient Holstein cows: An international response. J. Dairy Sci. 104:8983-9001. https://doi.org/10.3168/jds.2020-19889.

Méndez, M., P. Chilibroste, and M. Aguerre. 2020. Pasture dry matter intake per cow in intensive dairy production systems: Effects of grazing and feeding management. Animal 14:846-853. https://doi .org/10.1017/S1751731119002349

Miglior, F., A. Fleming, F. Malchiodi, L. F. Brito, P. Martin, and C F. Baes. 2017. A 100-year review: Identification and genetic selection of economically important traits in dairy cattle. J. Dairy Sci. 100:10251-10271.

Newton, J. E., R. Nettle, and J. E. Pryce. 2020. Farming smarter with big data: Insights from the case of Australia's national dairy herd milk recording scheme. Agric. Syst. 181:102811.

Pryce, J. E., O. Gonzalez-Recio, G. Nieuwhof, W. J. Wales, M. P. Coffey, B. J. Hayes, and M. E. Goddard. 2015. Hot topic: Definition and implementation of a breeding value for feed efficiency in dairy cows. J. Dairy Sci. 98:7340-7350.

Quinton, C. D., F. S. Hely, P. R. Amer, T. Byrne, and A. R. Cromie. 2018. Prediction of effects of beef selection indexes on greenhouse gas emissions. Animal 12:889-897 https://doi.org/10.1017/ S1751731117002373.

Richardson, C. M., C. F. Baes, P. R. Amer, V. R. Osborne, J. E. Pryce, and F. M. Miglior. 2019. Genetic parameters for multiple definitions of residual methane production in Australian dairy cattle. Page 131 in Proceedings of the International Symposium on Ruminant Physiology, Leipzig, Germany. Cambridge University Press.

Richardson, C. M., C. F. Baes, P. R. Amer, C. D. Quinton, F. S. Hely, V. R. Osborne, J. E. Pryce, D. Hailemarium, and F. M. Miglior. 2021a. Estimating the environmental impact of dairy cattle breeding programs through emission intensity. Animal 15:100005. 10.1016/j.animal.2020.100005.

Richardson, C. M., T. T. T. Nguyen, M. Abdelsayed, P. J. Moate, S. R. O. Williams, T. C. S. Chud, F. S. Schenkel, M. E. Goddard, I van den Berg, B. G. Cocks, L. C. Marett, W. J. Wales, and J. E. Pryce. 2021b. Genetic parameters for methane emission traits in Australian dairy cows. J. Dairy Sci. 104:539-549. https://doi.org/ 10.3168 /jds.2020-18565.

United Nations Framework Convention on Climate Change (UNFCCC). 2016. The Paris Agreement. Accessed Dec. 11, 2020 https://unfccc.int/process-and-meetings/the-paris-agreement/the -paris-agreement.

United Nations Framework Convention on Climate Change (UNFCCC). 2018. National inventory submissions. Accessed Nov. 2019. https://unfccc.int/process-and-meetings/transparency-and -reporting/reporting-and-review-under-the-convention/greenhouse -gas-inventories-annex-i-parties/national-inventory-submissions $-2018$.

Wall, E., C. Ludemann, H. Jones, E. Audsley, D. Moran, T. Roughsedge, and P. R. Amer. 2010. The potential for reducing greenhouse gas emissions for sheep and cattle in the UK using genetic selection. Final Report to DEFRA. DEFRA.

Williams, Y. J., J. E. Pryce, C. Grainger, W. J. Wales, N. Linden, M. Porker, and B. J. Hayes. 2011. Variation in residual feed intake in Holstein Friesian dairy heifers in southern Australia. J. Dairy Sci. 94:4715-4725. https://doi.org/10.3168/jds.2010-4015.

Workie, Z. W., J. P. Gibson, and J. H. J. van der Werf. 2019. Age at culling and reasons of culling in Australian dairy cows. Proc. Assoc. Advmt. Anim. Breed. Genet. 23:143-146.

Zhang, X., P. R. Amer, G. M. Jenkins, J. A. Sise, B. Santos, and C. Quinton. 2019. Predictions of effects of dairy selection indexes on methane emissions. J. Dairy Sci. 102:11153-11168. https://doi .org/10.3168/jds.2019-16943.

\section{ORCIDS}

C. M. Richardson @ https://orcid.org/0000-0003-4286-4969

P. R. Amer @ https://orcid.org/0000-0002-6428-7165

F. S. Hely ๑ https://orcid.org/0000-0002-6134-7142

I. van den Berg (1) https://orcid.org/0000-0002-9292-8636

J. E. Pryce ๑ https://orcid.org/0000-0002-1397-1282 